\title{
IMPACT OF BLACK SEEDSS Nigella sativa L. MEAL SUBSTITUTION INSTEAD OF SOYBEAN MEAL ON SOME GROWTH TRAITS OF LOCAL RABBIT MALES
}

\author{
Nadia M. B. AL-SHaar \\ Animal Production Department- College of Agriculture and Forestry / University of \\ Mosul/ Iraq \\ Emil: nmb@uomosul.edu.iq
}

\begin{abstract}
The work carried out on a privet local farm extended to eight weeks in Mosul city Iraq. Sixty local male rabbits, six to seven weeks aged, with an average initial bodyweight of $552 \pm 15 \mathrm{gm}$. Randomly divided into 4 treatments and 3 replications (5 rabbits each). Soybean meal replaced by black seeds (Nigella sativa L.) meals at levels $0,33,66$, and $100 \%$ respectively in the diets as a crud protein source. The diets were nearly equal in the level of energy digests and the percentage of crude protein. Treatment $4(100 \%)$ showed a significant effect $(\mathrm{p} \leq 0.05)$ in increasing daily weight gain, daily consumption, total weight gain, hot and cold carcass weight. A higher mortality percentage was in $\mathrm{T}^{1}(6.67)$. While our other results did not show any significant differences in all other studied traits. $\mathrm{T}^{4}$ showed the highest profit in weight gain (Kg) / Iraqi Dinar) then $\mathrm{T}^{3}, \mathrm{~T}^{2}$ and $\mathrm{T}^{1}$ respectively.
\end{abstract}

Keywords: rabbits, black seed meal, soybean meal

Received: 17/ 4 /2020, Accepted: 16/5/2020

\section{INTRODUCTION}

Soybean meal is one of the proteins sources that are widely used in rabbits' diet (El-Tohamy and El-Kady, 2007), it contains a high percentage of protein (NRC, 1994), and digestibility coefficient of crude protein $90 \%$ of rabbits (NRC, 1977). soybean meal is expensive being imported and this makes its price flocculent as well as its availability in the local market, hence it aroused the need to search for other nontraditional protein sources of good quality and low cost. black seeds meal (Nigella sativa) is characterized by having a high percentage of crude protein that amount to more than 40\% (Al-Azawy, 2012) and this crude protein is good quality (Abdullah and Al kahla, 2010). Additionally, its oil contains many active components such as Nigellimine, Nigellone (Ibrahim Al Khafaji, 2007). These components were proved to have an antibiotic, antifungal, and antioxidant effect, in addition, to increase the immunity of the body, reducing the harmful germs in the intestines, and reducing the thermal stress of the meat chickens (Ahmad et al., 2008, Al Khafaji and Al Jaryan, 2009). Feeding represents the larger portion of the overall expenses of farm animals, fowls, and rabbits breeding. Crude protein sources constitute the most expensive part of the diet components. The needs of the growing post- weaning rabbits of raw protein do not exceed 16-18\% of the diet (NRC, 1977and US Grains Council, 2003), therefore the diet required a high crude protein source to reach the necessary crude protein level. 
This study aims to know the impact of replacing the black seeds meal with soybean meal of local rabbits on some growth traits, productive performance, carcass characteristics, and economic feasibility. Possibility of replacing the soybean meal totally or partially by the black seeds meal (Nigella sativa) in the growth diet of the male rabbits, and its effects on some productive performance, carcass characteristics and the economic feasibility.

\section{MATERIALS AND METHODS}

This study was carried out in a private farm which is one of the local breeders in Mosul city/ Iraq for 8 weeks in which 60 male local rabbits ( hybrid species) with( 67 weeks aged), and approximately weights $552 \pm 15 \mathrm{~g}$ were bought from the local market of Mosul, and they were randomly divided in to 4 treatments with 3 replications each, contains 5 rabbits. Black seeds meal was used in percentages of 0 , $33,66,100 \%$ as a source of protein instead of soybean meal, representing $0,5,10$ and $15 \%$ for total diets research respectively. These diets were also approximately equal in the level of digested energy and the percentage of crude protein (Table 1). The concentrate ration and water were given to the growing rabbits ad libitum one week before starting the study, and this was adaptation period for the rabbits to get used to the new diets and environmental conditions, and continued throughout the whole period of the study. Rabbits were kept on a concrete floor in dimensions cages of $1 \times 4 \mathrm{~m}$ : each one has 5 rabbits and the hall was furnished with ventilators to keep the air fresh, get rid of the harmful gases and to keep the temperature between $22-25^{\circ}$. temperatures were measured by alcohol thermometer, whereas the relative humidity was between $60-80 \%$ and measured by a hygrometer with metal indicator (Al Jadir, 1994). Rabbits were labeled with metal numbers in the pinna of the right ear for follow up, then weighted after the preliminary period and considered the Initial weight. The rabbits were weighted weekly as well as the feed intake presented and the feed remained, to find the daily feed intake. Three rabbits out of each replicate were subjected to fasting at the end of study for 8 hours before slaughter. then they were weighed and was considered the afore- slaughter. Rabbits were slaughtered and features of the carcass were recorded and economic calculations were done for producing $1 \mathrm{~kg}$ gain of weight. Data were subjected to Statistical Analysis using the procedure of (SAS,2002) according to the following model: Yijk $=\mu+\mathrm{Fi}+$ eijK according to the following model: Characteristics were expressed as standard errors. Differences among means were tested using Duncan (Steel and Torrie, 1984). 
Table (1): Components of study rations and their calculated chemical analysis

\begin{tabular}{|c|c|c|c|c|}
\hline Components of ration & $\mathrm{T}^{1} 0 \%$ & $\mathrm{~T}^{2} 33 \%$ & $\mathrm{~T}^{3} 66 \%$ & $\mathrm{~T}^{4} 100 \%$ \\
\hline Black seeds meal & 0 & 5 & 10 & 15 \\
\hline Soybean meal & 15 & 10 & 5 & 0 \\
\hline Wheat bran & 20 & 24.52 & 29.04 & 33.56 \\
\hline Sunflower oil & 0.15 & 0.43 & 0.71 & 0.99 \\
\hline Barley & 20.60 & 15.80 & 11 & 6.20 \\
\hline Bread crumbs & 18 & 18 & 18 & 18 \\
\hline Cane's hay & 25 & 25 & 25 & 25 \\
\hline Caco3 & 0.50 & 0.50 & 0.50 & 0.50 \\
\hline Di calcium phosphate & 0.25 & 0.25 & 0.25 & 0.25 \\
\hline Vitamins and minerals & 0.25 & 0.25 & 0.25 & 0.25 \\
\hline Food salt & 0.25 & 0.25 & 0.25 & 0.25 \\
\hline Total & 100 & 100 & 100 & 100 \\
\hline \multicolumn{5}{|l|}{ Chemical analysis of diets } \\
\hline digested energy $\mathrm{Kcl} \mathrm{kg}$ & 2707 & 2707 & 2706 & 2706 \\
\hline Crude protein $(\%)$ & 16.20 & 16.19 & 16.16 & 16.14 \\
\hline $\begin{array}{l}\text { Percentage of digested energy: } \\
\text { Crude protein }\end{array}$ & 167.1 & 167.2 & 167.5 & 167.7 \\
\hline Dry matter & 91.20 & 91.34 & 91.47 & 91.62 \\
\hline Ether extract $(\%)$ & 2.08 & 2.94 & 3.78 & 4.64 \\
\hline Crude fiber $(\%)$ & 12.62 & 13.02 & 13.40 & 13.80 \\
\hline Ash (\%) & 6.70 & 6.73 & 6.77 & 6.80 \\
\hline Dissolved carbohydrates (\%) & 53.60 & 52.46 & 51.36 & 50.24 \\
\hline Organic matter $(\%)$ & 84.50 & 84.61 & 84.70 & 84.82 \\
\hline $\begin{array}{l}\text { Crude fiber ratio: dissolved } \\
\text { carbohydrates }\end{array}$ & 0.24 & 0.25 & 0.26 & 0.27 \\
\hline Crude fiber ratio: Crude protein & 0.78 & 0.80 & 0.83 & 0.86 \\
\hline $\begin{array}{c}\text { Crude protein content: dissolved } \\
\text { carbohydrates }\end{array}$ & 0.30 & 0.31 & 0.31 & 0.32 \\
\hline Lysine (\%) & 0.70 & 0.62 & 0.55 & 0.48 \\
\hline Methionine (\%) & 0.24 & 0.25 & 0.24 & 0.25 \\
\hline Calcium $(\%)$ & 0.64 & 0.67 & 0.72 & 0.77 \\
\hline Available phosphorus (\%) & 0.20 & 0.21 & 0.21 & 0.21 \\
\hline Linoleic acid (\%) & 0.78 & 1.27 & 1.75 & 2.24 \\
\hline
\end{tabular}

*- Feed components of the black seed, soybean, wheat bran, barley, bread crumbs and canes' hay were estimated in the laboratory according to AOAC (1995).

*- Amino acids, linoleic acid and minerals were calculated according to NRC (1994).

*- Digested energy of all the feed components were calculated according to the following formula:

Digested energy $(\mathrm{Kcl} / \mathrm{kg}$ dry matter $)=4253-32.6 *$ crude fibers- $144.4 * a s h$. (Feketeand Gippert, 1986). 


\section{RESULTS AND DISCUSSION}

Results showed in Table (2) the superior significantly $(\mathrm{p} \leq 0.05)$ the final body gain (g/rabbit) and the daily body gain (g/ day) in 4th group (15\% black seed meal) compared to the other treatments, whereas these differences $(\mathrm{p} \leq 0.05)$ indicated the preeminence of the first group compared to all the other treatments in the percentage of mortalities(6.67). The reason of significant differences in the total weight gains and the daily weights gain which due to might be attributed to the good balance of amino acids in the black seeds meal in and due to this meal having many active components such as Nigellimine, Nigellone, Thymoquinone Damascenine and others, and these components have an antibiotic, antifungal and anti-oxidant effects, also it increasing in body immunity which in its turn lead to enhancing the efficiency of protein transformation and consequently gain of rabbits. These results are in conformity with Zeweil et al., (2008), Shamsuldeen and Al Rawi (2011) and El- Nomeary et al., (2016), where they obtained significant increase in total weights of the treatments which they used the black seed meal with variant percentages in their study compared to the control treatments. The results contradicted with Abdullahand Al Kalha (2010) and Mehrez et al., (2011), where they did not find significant differences in the total gain of weight for the black seeds meal treatments compared to the control treatment. Results of daily weight gain were in conformity with El-Nattate and El-Kady (2007) and El-Nomeary et al., (2016), where they obtained a significant increase in the averages of this trait, when they used the black seeds meal with variant percentages in their experiments, compared to other treatments., whereas, the reason of significant differences in mortalities percentage might be due to the existence of many active components in the oil of the black seed meal that increase the body immunity and consequently reduce the percentage of mortalities with increasing the percentage of substitution by the black seed meal. The substitution of soybean meal by the black seed meal had no significant effects on the final weight of the living body (g/rabbit). These results confirmed the work of El- Tohamy and El Kady (2007), Abdullahand Al Kalha (2010) and Mehrez et al., (2011), where they didn't find significant differences in the characteristics of the living body in the treatments of black seed meal compared to other treatments. The results contradicted with El- Nattateand El-Kady (2007), Shamsuldeen and Al Rawi (2011) and El- Nomeary et al., (2016) who obtained significant differences in the feature of the final body weight in treatments in which they used the black seed meal compared to the control treatments.

In Table (3) the results confirmed non-significant differences in all the studied features, overall feed intake ( $\mathrm{g} \backslash$ rabbit), daily feed intake and the feed conversion ratio ( $g$. feed: $g$.weight gain) and ( $g$. feed: $g$. carcass) The results of overall and daily consumptions contradicted with Zeweil et al., (2008), Shams and-Al Rawi (2011), ElNattate and-El- Kady (2007) and El- Nomeary et al., (2016) who noticed the superior of significant differences in the average of total and daily feed intake of the rabbits fed with the diets of black seed meal compared with control whereas, the results of daily feed intake were in conformity with El- Tohamy and Al Kady (2007) who did not find 
Table (2): Effect of substituting soybean meal by different levels of black seeds meal on bodyweight, body gain, and mortality $\%$ of local rabbits

\begin{tabular}{|c|c|c|c|c|}
\hline Studied features & $\mathrm{T}^{1} 0 \%$ & $\mathrm{~T}^{2} 33 \%$ & $\mathrm{~T}^{3} 66 \%$ & $\mathrm{~T}^{4} 100 \%$ \\
\hline Initial body & 560.27 & 560.43 & 556.75 & 558.91 \\
weight (g/rabbit) & $38.15 \pm$ & $40.27 \pm$ & $45.11 \pm$ & $41.86 \pm$ \\
\hline Final body weight & 1085.45 & 1088.73 & 1121.18 & 1193.15 \\
(g/rabbit) & $82.53 \pm$ & $91.34 \pm$ & $100.05 \pm$ & $111.42 \pm$ \\
\hline Average daily & $9.38 \mathrm{~B}$ & $9.43 \mathrm{~B}$ & $10.08 \mathrm{~B}$ & $11.33 \mathrm{~A}$ \\
gain (g /day) & $0.87 \pm$ & $0.89 \pm$ & $0.84 \pm$ & $0.95 \pm$ \\
\hline Total gain (g/ day & $525.18 \mathrm{~B}$ & $528.30 \mathrm{~B}$ & $564.43 \mathrm{~B}$ & $634.24 \mathrm{~A}$ \\
/rabbit) & $37.30 \pm$ & $35.27 \pm$ & $50.57 \pm$ & $40.60 \pm$ \\
\hline \multirow{2}{*}{ Mortality \% } & $6.67 \mathrm{~A}$ & $0 \mathrm{~B}$ & $0 \mathrm{~B}$ & $0 \mathrm{~B}$ \\
& $0.52 \pm$ & $0 \pm$ & $0 \pm$ & $0 \pm$ \\
\hline
\end{tabular}

Values in the same column with different letters differ significantly $(\mathrm{P} \leq 0.05)$.

any significant differences in the feature of daily feed intake in the treatments of the black seed meal compared to the other treatments. The results of the feed conversion-ratio (g of feed: g of weight gain) were similar to Zeweil et al., (2008) who obtained a significant increase in the fodder transformation efficiency in the treatments of the black seeds meal compared to the control treatments, but our results contradicted with El- Nattate and El- Kady (2007), El- Tohamy and Al Kady (2007), Shamsuldeen and al Rawi (2011) and El- Nomeary et al., (2016) who did not found a significant differences in feed conversion ratio in black seed meal treatments. when they used it in the feeding of rabbits, compared to the control.

Table (3): The effect of replacement of the soybean meal with different levels of the black seeds meal on feed consumption of local rabbits.

\begin{tabular}{|c|c|c|c|c|}
\hline Studied features & $\mathrm{T}^{1} 0 \%$ & $\mathrm{~T}^{2} 33 \%$ & $\mathrm{~T}^{3} 66 \%$ & $\mathrm{~T}^{4} 100 \%$ \\
\hline Total Feed intake & 2325.65 & 2352 & 2411.42 & 2555.81 \\
\hline (g/rabbit) & $156.70 \pm$ & $150.34 \pm$ & $185.64 \pm$ & $206.10 \pm$ \\
\hline Daily Feed intake & 41.53 & 42 & 43.06 & 45.64 \\
\hline (g/rabbit/day) & $2.65 \pm$ & $3.22 \pm$ & $3.83 \pm$ & $4.47 \pm$ \\
\hline Feed conversion & 430 & 432 & 427 & 403 \\
\hline $\begin{array}{l}\text { ratio (g ration / } \\
\text { g weight gain) }\end{array}$ & $0.21 \pm$ & $0.05 \pm$ & $0.18 \pm$ & $0.67 \pm$ \\
\hline $\begin{array}{l}\text { Feed conversion } \\
\text { ratio (g ration/ } \\
\text { g carcass) }\end{array}$ & $\begin{array}{c}4.40 \\
0.25 \pm\end{array}$ & $\begin{array}{c}4.51 \\
0.31 \pm\end{array}$ & $\begin{array}{c}4.32 \\
0.04 \pm\end{array}$ & $\begin{array}{c}4.22 \\
0.15 \pm\end{array}$ \\
\hline
\end{tabular}

Different letters within the same row indicate the existence of significant differences at level of probability $(\mathrm{p} \leq 0.05)$

Results indicated a significant difference $(\mathrm{P} \leq 0.05)$ in hot and cold carcass weight in T4 (higher bodyweight of the living animal Before slaughtering g/rabbit) compared to other treatments Table (4) and this increased the dressing percentage. The differences were not significant in the carcass trait, which are the bodyweight before 
slaughter (g/rabbit), the dressing percentage with or without the edible guts, and the percentage of edible guts (\%).results of the cold and hot carcass weights were agree with Shamsuldeen and Al Rawi (2011), whereas, the weight of the hot carcass disagreed with Abdullah and Al Kalha (2010) and El- Nomeary et al., (2016). The results of body weight before slaughter agreed with Abdullah and Al Kalha (2010) and El-Nomeary et al., (2016), but not with Shamsuldeen and Al Rawi (2011). our dressing percentage results without the edible guts confirmed Bdullahand Al Kalha (2010), ElNomeary et al., (2016), El- Tohamy and Al Kady (2007) and Shamsuldeen and Al Rawi (2011) results. Also, with El-Tohamy and El-Kady (2007) and Sahmsuldeen and Al Rawi (2011) edible guts percentage.

Table (4): The effect of substituting soybean meal by variant levels of the black seeds meal on some features of the growing rabbit's carcass under study.

\begin{tabular}{|c|c|c|c|c|}
\hline Studied features & $\mathrm{T}^{1} 0 \%$ & $\mathrm{~T}^{2} 33 \%$ & $\mathrm{~T}^{3} 66 \%$ & $T^{4} 100 \%$ \\
\hline $\begin{array}{l}\text { Body weight } \\
\text { (g/rabbit) }\end{array}$ & $\begin{array}{l}1071.66 \\
50.19 \pm\end{array}$ & $\begin{array}{l}1074.03 \\
52.94 \pm\end{array}$ & $\begin{array}{l}1104.60 \\
97.65 \pm\end{array}$ & $\begin{array}{l}1180.86 \\
112.42 \pm\end{array}$ \\
\hline $\begin{array}{c}\text { Hot carcass weight } \\
\text { (g/rabbit) }\end{array}$ & $\begin{array}{l}535.08 \mathrm{~B} \\
28.35 \pm\end{array}$ & $\begin{array}{l}528.47 \mathrm{~B} \\
34.05 \pm\end{array}$ & $\begin{array}{l}563.97 \mathrm{~B} \\
41.11 \pm\end{array}$ & $\begin{array}{l}612.23 \mathrm{~A} \\
30.14 \pm\end{array}$ \\
\hline $\begin{array}{c}\text { Cold carcass weight } \\
\text { (g/rabbit) }\end{array}$ & $\begin{array}{l}529.05 \mathrm{C} \\
40.21 \pm\end{array}$ & $\begin{array}{l}521.33 \mathrm{C} \\
25.40 \pm \\
\end{array}$ & $\begin{array}{l}55.83 \mathrm{~B} \\
27.10 \pm \\
\end{array}$ & $\begin{array}{l}605.57 \mathrm{~A} \\
35.45 \pm\end{array}$ \\
\hline $\begin{array}{c}\text { Dressing percentage } \\
\text { without edible guts } \\
\%\end{array}$ & $\begin{array}{l}49.37 \\
1.05 \pm\end{array}$ & $\begin{array}{l}48.54 \\
1.22 \pm\end{array}$ & $\begin{array}{l}50.41 \\
0.95 \pm\end{array}$ & $\begin{array}{l}51.28 \\
2.67 \pm\end{array}$ \\
\hline $\begin{array}{c}\text { Dressing percentage } \\
\text { with edible guts \% }\end{array}$ & $\begin{array}{l}53.21 \\
2.42 \pm \\
\end{array}$ & $\begin{array}{l}52.43 \\
2.75 \pm \\
\end{array}$ & $\begin{array}{l}54.37 \\
3.18 \pm \\
\end{array}$ & $\begin{array}{l}55.39 \\
4.25 \pm \\
\end{array}$ \\
\hline $\begin{array}{c}\text { Percentage of edible } \\
\text { guts } \%\end{array}$ & $\begin{array}{c}3.84 \\
0.17 \pm \\
\end{array}$ & $\begin{array}{c}3.89 \\
0.17 \pm\end{array}$ & $\begin{array}{c}3.96 \\
0.25 \pm \\
\end{array}$ & $\begin{array}{c}4.11 \\
0.31 \pm\end{array}$ \\
\hline
\end{tabular}

Different letters within the same row indicate the existence of significant differences at probability $(\mathrm{p} \leq$ $0.05)$

Table 5 demonstrated the results of economic calculations to produce $1 \mathrm{~kg}$ weight gain for growing rabbits. The lowest feed costs (variable costs) were in treatment 4, which amounted to 1132 Iraqi dinars, where the highest cost of consumer feed was in treatment 1 , amounting to 1638 Iraqi dinars. The reason is that the lowest price per $\mathrm{kg}$ of feed is 281 dinars, and it has a conscious increase in weight (consumed feed = price of a $\mathrm{kg}$ of feed $*$ average feed consumption $/ \mathrm{Kg}$ total weight gain). Treatments 1,2 , and 3 had the lowest fixed costs 1850 Iraqi dinars / Kg total weight gain. Treatment 1 has the highest fixed costs of 1982 dinars due to a high death rate of $6.67 \%$ compared to the other treatments. Also, able 5 also indicated that the overall costs (the summation of variable and fixed costs) decreased with the increase in the percentage of substitution by the black seed meal. This makes treatment 4 the lowest with 2981 ID/kg weight gain and the treatment 1 the highest $3620 \mathrm{ID} / \mathrm{kg}$ weight gain. These results agree with Abdullah and Al Kalhas's (2010) result, were reported that the overall costs reduce with the increase of the black seed meal percentage. Total revenue was highest in treatment $4(7159 \mathrm{ID} / \mathrm{kg}$ weight gain) and the least was treatment 1 (6513 ID/kg weight gain) (revenue $=$ the price of $1 \mathrm{~kg}$ live body weight $*$ average weight of rabbit) assuming that the sale price of $1 \mathrm{~kg}$ live body weight is $6000 \mathrm{ID}$. 
Treatment 4 has the highest profit with 4177 ID $/ \mathrm{kg}$ weight gain, whereas the treatment 1 recorded 2893 ID $/ \mathrm{kg}$ weight gain. thus, the treatment ranks according to the profit were 4, 3, 2, 1 respectively. The profit results were similar to those of Mehrez et al., (2011), but, contradicted with El-Tohamyand El-Kady (2007). Finally, the Table showed the price of $1 \mathrm{~kg}$ of feed for each treatment of the research which was $(370$, 341,311 , and 281) ID/ $\mathrm{kg}$ feed respectively.

Table (5): The effect of substituting soybean meal with variant levels of the black seeds meal on economic calculations to produce $1 \mathrm{~kg}$ weight gain of a growing rabbit after 8 weeks from the beginning of the study

\begin{tabular}{|c|c|c|c|c|}
\hline Economic calculations & $\mathrm{T}^{1} 0 \%$ & $\mathrm{~T}^{2} 33 \%$ & $\mathrm{~T}^{3} 66 \%$ & $\mathrm{~T}^{4} 100 \%$ \\
\hline $\begin{array}{c}\text { Consumed fodder } \\
\text { costs (ID/kg weight } \\
\text { gain) }\end{array}$ & 1638 & 1518 & 1329 & 1132 \\
\hline $\begin{array}{c}\text { Other costs (ID/kg } \\
\text { weight gain) }\end{array}$ & 1982 & 1850 & 1850 & 1850 \\
\hline $\begin{array}{c}\text { Overall cost (ID/kg } \\
\text { weight gain) }\end{array}$ & 3620 & 3368 & 3179 & 2982 \\
\hline $\begin{array}{c}\text { Return (ID/kg weight } \\
\text { gain) }\end{array}$ & 6513 & 6532 & 6727 & 7159 \\
\hline $\begin{array}{c}\text { Profit (ID/kg weight } \\
\text { gain) }\end{array}$ & 2893 & 3164 & 3548 & 4177 \\
\hline Profit rank & 370 & 341 & 311 & 281 \\
\hline Cost of 1 kg diet (ID) & & 3 & 2 & 1 \\
\hline
\end{tabular}

\section{CONCLUSIONS}

It could be recommended to replace soybean meal by the black seeds meal $100 \%$ in local rabbits diets after weaning, as the results did not show significant differences in the final body weight, feed intake, feed conversion ratio ( $\mathrm{g}$ feed: $\mathrm{g}$ weight gain) and ( $\mathrm{g}$ feed: carcass weight) and in the dressing percentage with or without edible guts. The complete substitution was also significantly the best regarding the total weight gain and in cold and hot carcass weights (g/rabbit). Treatment 4 also had the best profitability (ID/kg body weight gain).

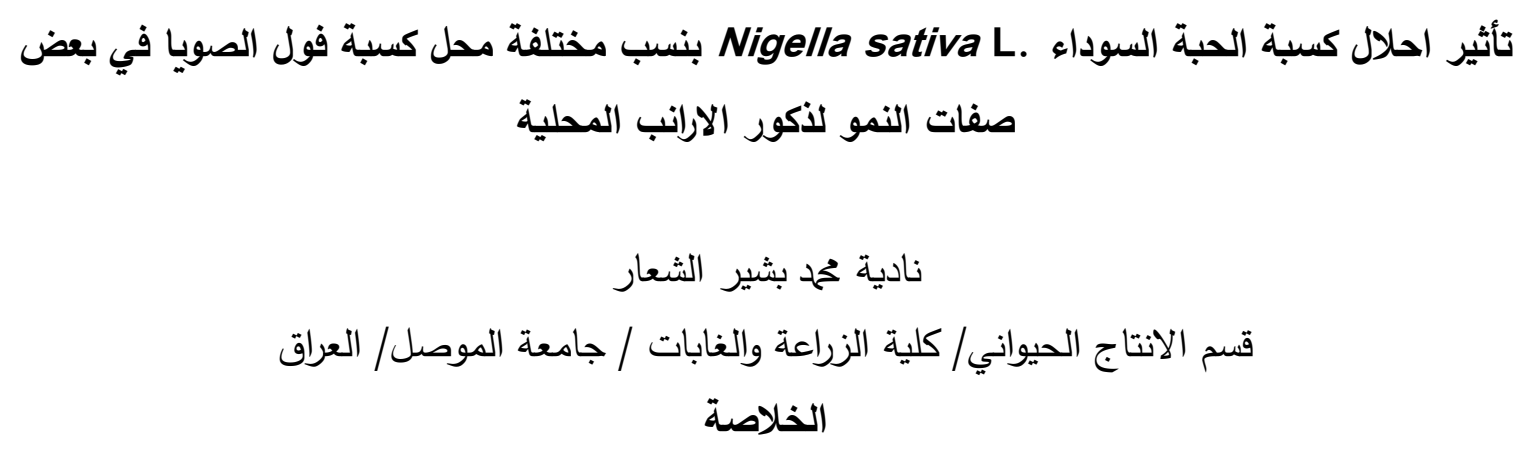

اجريت هذه الدراسة لمدة 8 أسابيع في أحد مزارع المربين المحليين في مدينة الموصل. استخدم فيها 60 ذكرا من الأرانب المحلية بعمر 6-7 أسابيع وبأوزان متقاربة بحدود 552 × 15 غم، قسمت الأرانب عشوائيا إلى 4 
معاملات في كل منها 3 مكررات في كل مكرر 5 أرانب، تم في هذه التجربة إحلال كسبة الحبة السوداء بنسب 0 ، 33 ، 66 و 100\% بوصفها مصدرا بروتينيا بديلا عن كسبة فول الصويا في علائق نمو الارانب المحلية المستخدمة في الدراسة. وكانت العلائق متساوية تقرببا في مستوى الطاقة المهضومة ونسبة البروتين الخام. أظهرت نتائج هذه الدراسة وجود فروقات معنوية (أ > 0.05) لصالح المعاملة الرابعة في صفة الزيادة الوزنية الكلية والزيادة الوزنية اليومية ووزن الذبيحة الحارة والباردة كذلك اشارت النتائج ان اعلى نسبة هلاك كانت للمعاملة الأولى (أ > 0.05) حيث كانت 6,67 \% في حين لم تظهر النتائج أية فروقات معنوية في جميع الصفات المدروسة الاخرى. أما أفضل ربح (دينار عراقي/كغم زيادة وزنية) فكان للمعاملة الرابعة ثم الثالثة ثم الثانية فالأولى.

الكلمات المفتاحية: ارانب، كسبة الحبة السوداء، كسبة فول الصويا. تاريخ تسلم البحث: 17 / 4 / 2020 ، وقبوله: 16 / 5 /

\section{REFERENCES}

Abdullah, N. M. and A. A. M. Al-Kahlah ( 2010). The effect of substituting black seed kernel as a source of protein in local rabbit diets on their productive characteristics and carcass characteristics. Iraqi Journal of Veterinary Science. 24 (1): 59 - 63.

Ahmad, I. S., S. A. Naji and H. I Al-Hiti (2008). The effect of adding Nigella sativa black seed powder to the bush during the last four weeks of life on some physiological and immunological properties of broilers. Iraqi Agriculture Journal. 13 (2): 116-122.

Al-Azzawi, Y. G. S. (2012). The effect of substitution of black seed meal instead of soybean meal on some productive characteristics of broilers. Kirkuk University Journal of Agricultural Sciences. 3 (1): 44 - 56.

Al-Jader, M. A. (1994). Breeding Rabbits (Theoretical Part). Ibn Khaldun Press Aleppo - Syria.

Al-Khafaji F. R. A. and I. L. AL-jaryan (2009). The effect of adding Nigella sativa seed powder to the diet on some productive and physiological characteristics of Lohmann meat broilers exposed to high temperatures. Al-Qadisiyah Journal for Veterinary Science. 8 (1): 63-70.

Anonymous (1996). Statistical Analysis System, SAS user's guide: statistics, SAS, Inc., Cary, N.C., USA.

Anonymous (1995). Official Methods of Analysis. 16th ed., Association of Official Analytical Chemists, Washington DC, USA.

EL-Nattat W.S. and R.I. EL-Kady (2007). Effect of different medicinal plant seeds residues on the nutritional and reproductive performance of adult male rabbits. Int J Agric Biol. 9 (3): 479 - 485.

EL-Nomeary, Yasser A. A., R. I. EL-Kady, A. A. El-Shahat and Walid S. EL-Nattat (2016). Prolonged effect of some plant seeds meals supplementation on the performance and serum parameters in male rabbits. Int. J. Chem. Tech. Res. 9 (12): $68-80$. 
EL-Tohamy, M.M. and R.I. EL-Kady (2007). Partial replacement of soybean meal with some medicinal plant seed meals and their effect on the performance of rabbits. Int J Agric Biol. 9 (2): 215 - 219.

Fekete S. and T. Gippert (1986). Digestibility and nutritive value of nineteen important rabbit feedstuffs. J. appl. Rabbit Res. $9: 103-108$.

Ibrahim Z. K. and F. R. Al khafaji (2007). The effect of adding Nigella sativa black bean powder to the diet on the feed and water consumption pattern and some productive characteristics of the heated broiler meat. Iraqi Poultry Science Journal. 2 (3): 36--51.

Mehrez, A. Z., M. A. EL-Harairy and M. M. M. Salama (2011). Effect of using black seed on growth performance and economical efficiency of rabbits. J. Animal and poultry prod., Mansoura Univ., 2 (2): 13-21.

Narrator, K. M. and A. S. Abdul Aziz (2000) Design and Analysis of Agricultural Experiments. Ibn Al-Atheer Press for Printing and Publishing, University of Mosul. Iraq.

National Research Council, (1977). Nutrient Requirement of Rabbit. $2^{\text {nd }}$ ed National Academy Press. Washington D, C., USA.

National Research Council, (1994). Nutrient Requirement of Poultry. $9^{\text {th }}$ ed National Academy Press. Washington D.C., USA.

Shams al-Din Q.Z. and E. A. Al Rawi (2011). Some of the productive and physiological traits of local male rabbits that are fattened on diets contain black bean meal. The Fifth Scientific Conference of the Faculty of Agriculture - Tikrit University, 26-27 April.

Zeweil HS, Ahmed MH, EL-Adawy MM, Zaki (2008) Evaluation of substituting Nigella seed meal as a source of protein for soybean meal in diets of New Zealand white rabbits. 9th World Rabbit congress, June10-13, Verona-Ita. 